\title{
Drinking dangerously? Young football fans, alcohol and masculinity in Brazil
}

http://dx.doi.org/10.11606/1807-5509201800020277

\author{
Heloisa Helena Baldy dos REIS* \\ Mariana Zuaneti MARTINS** \\ Ramón SPAAIJ $J^{* * * * * * * *}$ \\ Felipe Tavares Paes LOPES ${ }^{* * * * *}$
}

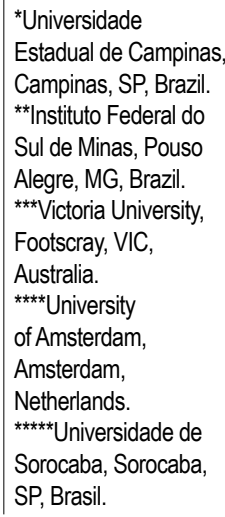

\begin{abstract}
This article examines young members of football fan formations known as torcidas organizadas and their relationship with alcohol. This relationship is investigated drawing on a survey undertaken with 804 young football fans in the State of São Paulo, Brazil. The survey results indicate that the percentage of young fans who engage in heavy drinking is considerably higher than that for young Brazilians of the same age in general. Through comparison with young football fans from other countries, it is argued that this high rate is related to the cultural practices of young torcedores, in which drinking 'dangerously' is a constitutive element in their construction of masculinity in the football context.
\end{abstract}

KEYwORDS: Football; Alcohol; Torcidas organizadas; Masculinity; Fandom.

\section{Introduction}

The relationship between alcohol and sports has been studied for some decades ${ }^{1,2}$. The mainstream studies on this matter argued that contradictory sports are related to health and the alcohol consume, in particular, sport spectator drinking. Therefore, any health promotion policy would to take in account this association ${ }^{1}$. However, when the subject is the relationship between sports spectators' violence and alcohol, the matter is a more complex.

Sociological and anthropological research debunks the popular belief that alcohol is implicated in many instances of football-related violence. For example, DunNING $^{3}$ argues that alcohol consumption is not a root cause of football-related violence for the simple reason that not every fan who drinks in a football context acts aggressively or violently, not even those who drink heavily. Some football crowds with a reputation for heavy drinking, such as fans of the Scottish and Danish national football teams, do not have a reputation for violent conduct ${ }^{4,5}$. These fans, although often associated with excessive alcohol consumption, are typically identified with a nonviolent carnival atmosphere where drunkenness is accompanied by positive sociability ${ }^{6}$. Conversely, not all of those who do get involved in violence drink. In some cases fans deliberately seek to keep a clear head in order to maintain their ability to fight and avoid being caught unawares by rival fans or the police. Instead, Dunning argues the relationship between football violence and alcohol consumption is indirect. Not violence, but the masculinity norms of the fan groups involved that tend to stress the ability to drink (copious amounts of) alcohol as something of which to be proud and as a symbol of masculinity. This finding is consistent with broader research which suggests that alcohol consumption is associated with the performance of masculine identity ${ }^{7,8}$. 
Ethnographic studies that analyze football fandom as a contemporary form of carnival lend further weight to this argument ${ }^{5,9-11}$. Football fandom can be seen to facilitate a period of ritualized transgression from the norms of everyday life and a collapse or inversion of the normal roles that people are forced to play in society. PeArson's ${ }^{11}$ ethnography of English football fans shows how fans' experience of the carnivalesque is based upon congregating in groups, alcohol consumption, humour and expressions of identity. The fan groups Pearson studied were frequently brought into conflict with the football authorities and police, and alcohol was often a key object of contention. Several alcohol restrictions have been imposed on football fans, such as bans on drinking on transport to matches, prohibitions on the sale of alcohol in stadia, and the closing of bars around the stadium on match days. In England, for example, it was "allowed the regulated sale of beer in the stadium, limiting the amount of pints (the classic British measure) per spectator, and a ban on entering with drinks in the stands. One could drink before the matches and during the breaks of the matches" (p. 29) ${ }^{12}$. It was due to the Dry Law. This "could be effective in small towns, but in London - where a few hundred meters walk from the stadium, the fans can find a pub that works legally-, such measure made no sense" (p. 29) ${ }^{12}$. Yet, in other European countries such as Germany, the alcohol sale still allowed throughout the game. Alcohol restrictions typically have little or no impact on levels of alcohol consumption or drunkenness; rather, they can actually create situations where conflict and confrontation are more likely ${ }^{11,13}$. Anyhow, research on the relationship between alcohol consuming and violence still something scarce in Brazil, as we will discuss later.

In Brazil, young fans from torcidas organizadas are systematically accused by sports administrators, public officials and the media of being responsible for acts of violence and vandalism that occur inside and outside Brazilian sports stadiums and hence we studied them. These same public actors often refer to young football fans as 'lazybones', 'tramps' and 'bandits' ${ }^{14}$. Rather than reliable representations of reality, these popular stereotypes are, at least for those on the receiving end, abusive and discriminatory. We know that only a small minority of young torcedores (fans) engage in violent behaviour in the football context ${ }^{15}$.

The association of the torcidas organizadas with the violence related to the Brazilian football appeared in the 1980s. According to Thompson, Palmer and RAVEN ${ }^{16}$, this was mainly with the prominence given by the press to the murder, in 1988, of one of the founders and leaders of Mancha Verde, from the team Palmeiras. In the following decade, this association was strengthened and violence in football gained an increased public dimension and became an item on the agenda of policy decisions. One episode in particular seems to have caught the attention of the media and the authorities: the 1995 'Battle of Pacaembu', when fans of Palmeiras and São Paulo invaded the pitch and engaged in violent clashes, resulting in the death of a fan and more than one hundred injuries.

It was also in the first half of the 1990s that the torcidas organizadas grew significantly. For example, from 1991 to 1995 , the main torcidas organizadas of São Paulo quadrupled their membership: Mancha Verde grew from 4,000 to 18,000 members, Independente from 7,000 to 28,000 and Gaviōes da Fiel from 12,000 to $46,000^{17}$. In the 2000 s, the membership of these fan groups kept rising, and, in some cases, nearly doubled. However, despite this growth, Murad ${ }^{15}$ reminds us that the members of torcidas organizadas continue to be only a small fraction of all fans.

The symbolic aspect is one of the most important in the definition of torcidas organizadas. It is based upon the recognition and the difference between these supporters, reinforcing and expressing ' $[\ldots]$ the commitment and belonging to the group, since the symbols demarcate differences and identities, solidifying opposition and solidarity' (p. 91) ${ }^{18}$. Torcidas organizadas can be easily recognized in stadiums with their own clothes, choreography and 'war chants'. Their members also often seek to defend their territoriality, and, as indicated by MONTEIRo ${ }^{19}$, share and spread an aggressive, hyperheterosexual masculine identity which, among other things, leads to discrimination against homosexuals and others deemed 'non-masculine ${ }^{20}$. As will be seen below, alcohol consumption plays a significant part in the fans' masculine and territorial performances. In the next section we will discuss the methodological approaches taken to investigate this issue.

Given this, it is necessary to move beyond popular beliefs and stereotypes to investigate who those young members of torcidas organizadas really are and how they give meaning to their football fandom. Such investigation is pivotal to the development of appropriate public policies. As such, our study builds on, and is situated within, the rich body of international research on football fans which seeks to make visible, describe and come to an understanding of how football fans give meaning to and experience their social world ${ }^{11,21-24}$. 
The specific focus in this paper on the issue of alcohol is due, primarily, to the fact that research into the sport-alcohol nexus in Brazil is still very scarce $^{25,26}$. International research, both academic and journalistic, points to a high consumption of alcohol by young football fans, indicating a close relationship between their lifestyles and alcohol consumption ${ }^{21,27-29}$. Alcohol consumption forms an important part of the match-going experience for many football fans; yet, this is not necessarily the case. Recent research shows that the common perception that sports fans routinely engage in excessive drinking is seriously flawed because it fails to recognize the diverging ways in which fans engage with, or abstain from, alcohol ${ }^{16}$. Moreover, there is disagreement among scholars as to the nature and implications of alcohol consumption among sports fans ${ }^{8}$. Much of this discussion has focused on the effects of alcohol on aggressive fan behaviour (e.g. RusselL ${ }^{18}$ ).

\section{Methoda $^{\text {a }}$}

Prior to showing the data, we have to make some some reservations regarding to our sample. First, there is great difficulty in determining what is the total population studied, since, as much as there is a legal mandatory register of torcedores organizados, this does not reflect the universe of fans that go to the stadium. The reason of this fact is that many of the registeres torcedores organizados are not paying annuity and even those who go regularly to stadiums. An example is that one of the torcidas have 70,000 associated supporters, however, its management claimed to have an active part paying of 5000 fans. Second, even with the information of how many associated pay, we still may not assert accurately whether it reflects the members who attend the stadiums, the ones who are the object for the purpose of our research.

Due to the difficulty of defining the study population, and therefore the use of a random sample, we chose to use a non-probabilistic sample, by intention. According to Costa $\mathrm{NetO}^{30}$, where the population can not be defined, the researcher must choose to select a sample that is able to study. Such sampling, however, may be interesting as a way to complement the qualitative research ${ }^{31}$, as it can be assumed in our research.

The criterion of our sample was intentional. According to Romera and ReIs ${ }^{30}$, the sample is intentionally defined by the researchers, from the
Given the complexity of the relationship between the consumption of alcohol, torcidas organizadas and violence, this paper investigates the profile of torcedores organizados, from their relationship with alcohol. This paper is part of a long-standing research programme that was designed to inform Brazilian public policy around the prevention of violence at sporting events, first initiated in March 2003. This article seeks to ascertain if, in the State of São Paulo, the relationship between match-going culture and alcohol consumption also exists and, if so, to ascertain its possible reasons and implications. Before addressing these issues, it is important, however, to contextualize the phenomenon of torcidas organizadas. We will do so below by indicating the formation process of these supporters as well as their ways of organization and operation.

judging criteria considered by it valid. In our case, we opted for intentional sample by biotipia, where we sought for male fans in the entrance to the stadium next to the specific sector of torcidas organizadas and they appeared to be 15-25 years-old. As MURAD ${ }^{15}$ and Spanish Senate ${ }^{27}$, this group of fans are mainly responsible for the occurrence of violent incidents related to football.

Interviews were conducted in three stadiums in the city of São Paulo, in matches of: the State Championship, in March 2007 and 2008; the Brazilian Championship in May, July and August 2008; and the Copa Libertadores 2008. The selection of matches in which the interviews would be made respected the criterion of mandatory club. Interviewers were all university students (undergraduate and graduate), which were prepared for the interviews. The number of interviewers ranged from nine to fourteen per game, the variation was due to the availability of staff. We interviewed 264 people of torcida $A, 277$ from torcida $B$ and 263 torcida $C$.

According to Costa $\mathrm{NeTO}^{30}$, the non-probabilistic sample is used to generate hypotheses about the studied object. Therefore, we intend with this questionnaire to add more elements on the discussion of the torcedores organizados and alcohol in Brazil, to be able to support higher further research on the issue and public health policies of youth and security in stadiums. 
For data production, we conducted structured interviews with eleven closed questions and four open ones with torcedores organizados, which attend to football matches from the three largest torcidas orgnizadas of the State of São Paulo. In addition to these questions, with regard specifically to alcohol, we enclosed in the interviews the Alcohol Use Disorders Identification Test (AUDIT), a probe test developed by the World Health Organization $(\mathrm{WHO})^{33}$ and adapted to Brazil by Mendez ${ }^{34}$ (and subsequently validated by Lima et al..$^{35}$ ) to identify persons whose alcohol consumption has become hazardous or harmful to their health. The use of the AUDIT screening procedure in primary health care settings is linked to a decision process that includes brief intervention with heavy drinkers, or referral to specialized treatment for patients who show evidence of more serious alcohol involvement. AUDIT consists of ten closed questions, with three questions on the amount and frequency of drinking, three questions on alcohol dependence, and four questions on problems caused by alcohol.

The score for each question ranges from one to four, which allows a maximum total of forty points. Scores between one and seven indicate 'moderate drinking', scores between eight and fifteen points indicate 'risk drinking', and scores between sixteen and nineteen points are considered 'high-risk drinking'. A score of twenty points or more is recommended further evaluation of possible alcohol dependence ${ }^{36}$. Persons who have a score of less than eight are considered 'negative' because they do not represent 'problematic' use of alcohol, while those who exceed eight points are considered 'positive', pointing to 'risk' ${ }^{37}$.

Our analysis was based on the descriptive statistics, summarizing measures of our sample. We presented variables in terms of frequency distribution, depicted as tables and graphies. This quantative approach is a significant departure from the orthodoxy of research on young male football fans and alcohol consumption. Ethnographic approaches feature centrally in the body of scholarship on football fans (Association football as well as other football codes) $)^{9,11,19,21,28}$. We consider these different approaches to be complementary, where the findings from one method can be used to elaborate, clarify, explain or illustrate the results from another. Specifically, the broad, externally valid, relationships among variables uncovered through the survey employed in our study provide an important addition to the contextual understanding produced by these qualitative studies. Our decision to use a quantitatively orientated approach was informed by the lack of Brazilian research on the relationship between football fans and alcohol consumption, where a quantitative study could serve as a foundation for further qualitative (and quantitative) research.

\section{Results and Discussion}

The research results may lead to different discussions. For the present purpose, however, we focus on the findings relating to alcohol consumption and present some explanations for them.

A total of 804 people were interviewed for this study. Of these, $19.2 \%$ are of black people descent.
Minors are a minority $(26.9 \%)$, a percentage that is lower than the impression that the leaders of torcidas organizadas have of their membership, as we were told in our first contact with them. The most common ages among respondents were 25 years $(13.8 \%)$ and 18 years $(13.8 \%)$. The age distribution of interviewees is shown in TABLE 1 .

TABLE 1 - Age distribution.

\begin{tabular}{ccccc}
\hline Age & Frequency & Valid percent & Cumulative Percent & \\
\hline 15 & 49 & 6,1 & 6,1 & \\
16 & 69 & 8,6 & 14,7 & \\
17 & 98 & 12,2 & 26,9 & \\
18 & 106 & 13,2 & 40 & \\
19 & 76 & 9,5 & 49,5 & \\
20 & 74 & 9,2 & 58,7 & To be continued \\
\hline
\end{tabular}


Continued

TABLE 1 - Age distribution.

\begin{tabular}{cccc}
\hline Age & Frequency & Valid percent & Cumulative Percent \\
\hline 21 & 71 & 8,8 & 67,5 \\
22 & 56 & 7 & 74,5 \\
23 & 49 & 6,1 & 80,6 \\
24 & 45 & 5,6 & 86,2 \\
25 & 111 & 13,8 & 100 \\
Total & $\mathbf{8 0 4}$ & $\mathbf{1 0 0}$ & \\
\hline
\end{tabular}

On the use of alcohol, we found that $67.2 \%$ of interviewees did not consume alcohol or use it in a 'moderate' way. In contrast, $32.8 \%$ indicated use of alcohol in a 'risk' or a 'high risk' way because they reported more than eight items on the AUDIT, which indicates that this is a vulnerable group. This finding reflects the results of a previous study by RoMERA and ReIs ${ }^{32}$ that investigated members of one specific fan group in the state of São Paulo and found that $36.9 \%$ of young men between the ages of 15 and 25 years frequently drink alcohol. In the 'positive' group, $26.9 \%$ are minors.

The main finding to be discussed here is the fact that $32.8 \%$ of survey respondents consume alcohol in a 'risky' way, according to the criteria of the AUDIT. This percentage is higher than the alcohol consumption of Brazilian youth of the same age in general. A population-based study carried out in southern Brazil found that 14.5\% of men and $8.3 \%$ of young people aged $15-29$ had a positive AUDIT score (compared to $2.4 \%$ of women) and identified them as having a potential alcohol consumption problem ${ }^{38}$. A study in the State of São Paulo found a similar prevalence of alcohol abuse/dependence: $13.1 \%$ of men had a positive AUDIT score, and the frequency was higher among young adults aged 14-39 years than for other age groups ${ }^{39}$. In Brazil, $24 \%$ of young people under the age of 18 drink at least once a month, while $22 \%$ of young people aged between 18 to 24 years drink one to four times a week ${ }^{40}$. Roughly a quarter of people in this age group drink five to eleven drinks per occasion, so that 'the number of doses drunk in a single day may turn leisure into a harmful use of alcohol, damaging to health, ranging from disease exposure to the risk of serious accidents' (p. $19^{17}$ ).

On the matter of scolarity, the results show that alcohol consumers have studied more years than non risk alcohol consumers, as shown in TABLE 2:

TABLE 2 - Education level.

\begin{tabular}{lcccc}
\hline & Frequency & Percent & Valid Percent & Cumulative Percent \\
\hline Illiterate & 2 & 0,2 & 0,3 & 0,3 \\
Not completed Pre-School & 2 & 0,2 & 0,3 & 0,6 \\
Not Completed Primary School & 34 & 4,2 & 4,3 & 4,9 \\
Junior High graduate & 34 & 4,2 & 4,3 & 9,1 \\
Not finished high school & 251 & 31,2 & 31,5 & 40,6 \\
High school graduate & 255 & 31,7 & 32 & 72,6 \\
Incomplete bachelor degree & 151 & 18,8 & 18,9 & 91,5 \\
Bachelor degree & 64 & 8 & 8 & 99,5 \\
Professional Master or Doctorate Degree & 4 & 0,5 & 0,5 & 100 \\
Total & 797 & 99,1 & 100 & \\
Missing & 7 & & 0,9 & \\
Total & 804 & & & \\
\hline
\end{tabular}


In the studied age group, it was expected that the majority of the interviewed would be studying either in high school or in higher education. The observed data in TABLE 2 show a compatibility between age and years of schooling: $32 \%$ had completed high school; $31.5 \%$ had not finished high school; $18.9 \%$ had incomplete higher education; $8 \%$ had completed higher education; $0.5 \%$ were graduates and $0.3 \%$ were illiterate. We could notice, therefore, the prevalence of good schooling level among them, in addition, other supporters were in the process of schooling compatible with age, with the exception of the illiterate. The full distribution of levels of education can be seen in the following table. Among the 'positive' group, 33.6\% have completed tertiary schooling, followed by $25.9 \%$ who have incomplete higher education and $23.6 \%$ who have incomplete tertiary schooling. Data that indicate a level of education consistent with what was expected for the age group. However, it is significant that this results points that who scored positive in AUDIT test have studied more years than those who didn't. Result that is different from BARROS et al. ${ }^{39}$ who showed that the prevalence of alcohol abuse was significantly higher among those who studied less than 12 years of school.

Nearly $7 \%$ of those who scored "positive" are married; $85.2 \%$ of those with a 'positive' score live with their parents or with one of them; $4.2 \%$ live alone and $21.2 \%$ declare themselves as black. Regarding family organization, the majority of supporters in our sample $(78.7 \%)$ are not the provider of the family, while $16 \%$ is, as we can see in FIGURE 1. On the marital status of the interviewed, the majority $(93.4 \%)$ is single and $6.5 \%$ is married, as in FIGURE 2. This means that there is a group among torcedores organizados that is responsible for their family even though they not married. The vast majority of interviewees $(87.5 \%)$ stated that they live with both parents or one of them, i.e. with their original family. The own family is constituted by $7.3 \% ; 1.5 \%$ live with relatives; $3.1 \%$ live alone and $0.6 \%$ live with other people, as FIGURE 3 . As we can see in the figures, a comparasion of those who scored 'positive' and 'negative' in AUDIT does not show significant differences.

More than half (58.2\%) of the interviewed fans who scored positive on AUDIT self-identified as Catholic; $29.7 \%$ reported not having a religion; $2.7 \%$ reported to be Evangelical and 9.5\% identified with other religions.

FIGURE 4 also shows that the prevalence of alcohol abuse is higher among those who declare to do not have religion or another religion not protestant, result that is similar to the founds of BARROS et al. ${ }^{39}$.

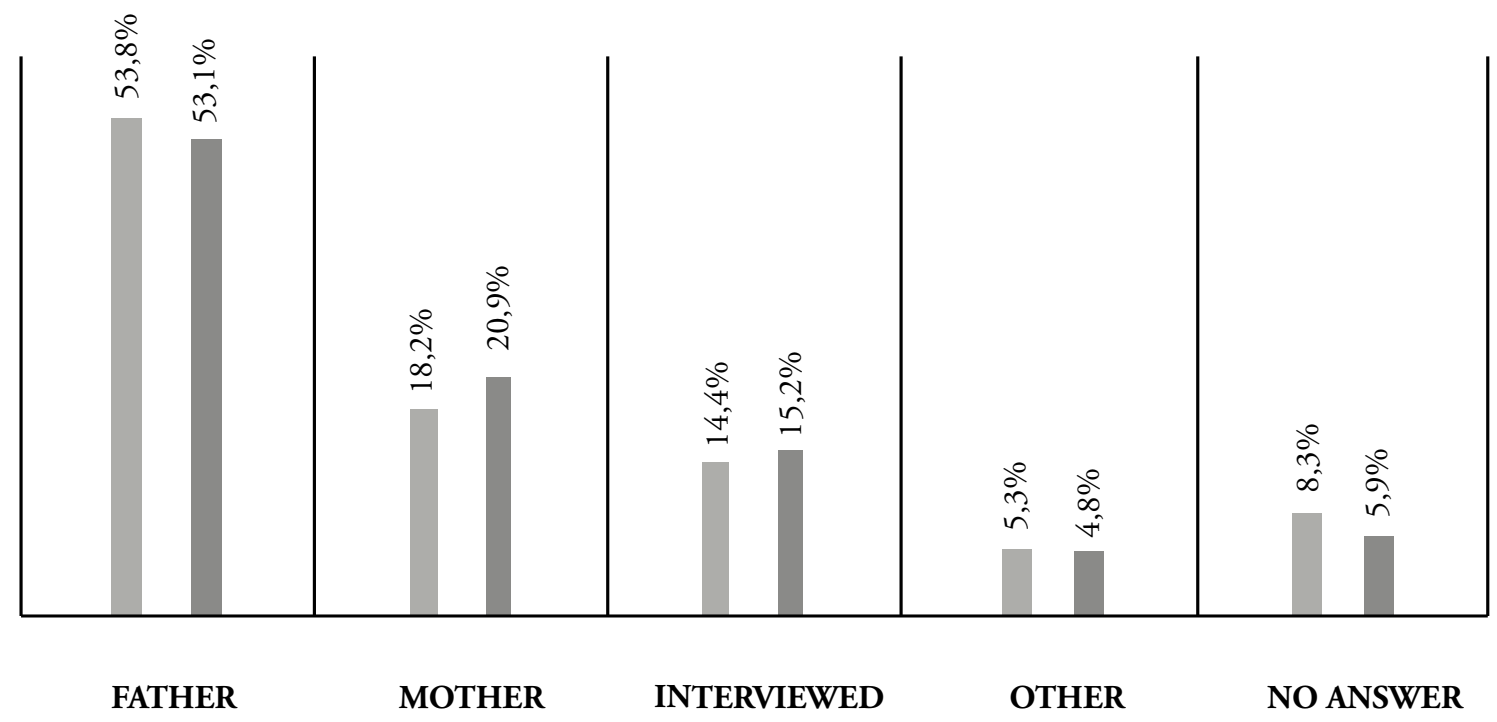

AUDITPositive

AUDITNegative

FIGURE 1 - Who is the household of the interviewed's family?

Font: Elaborated by the authors. 


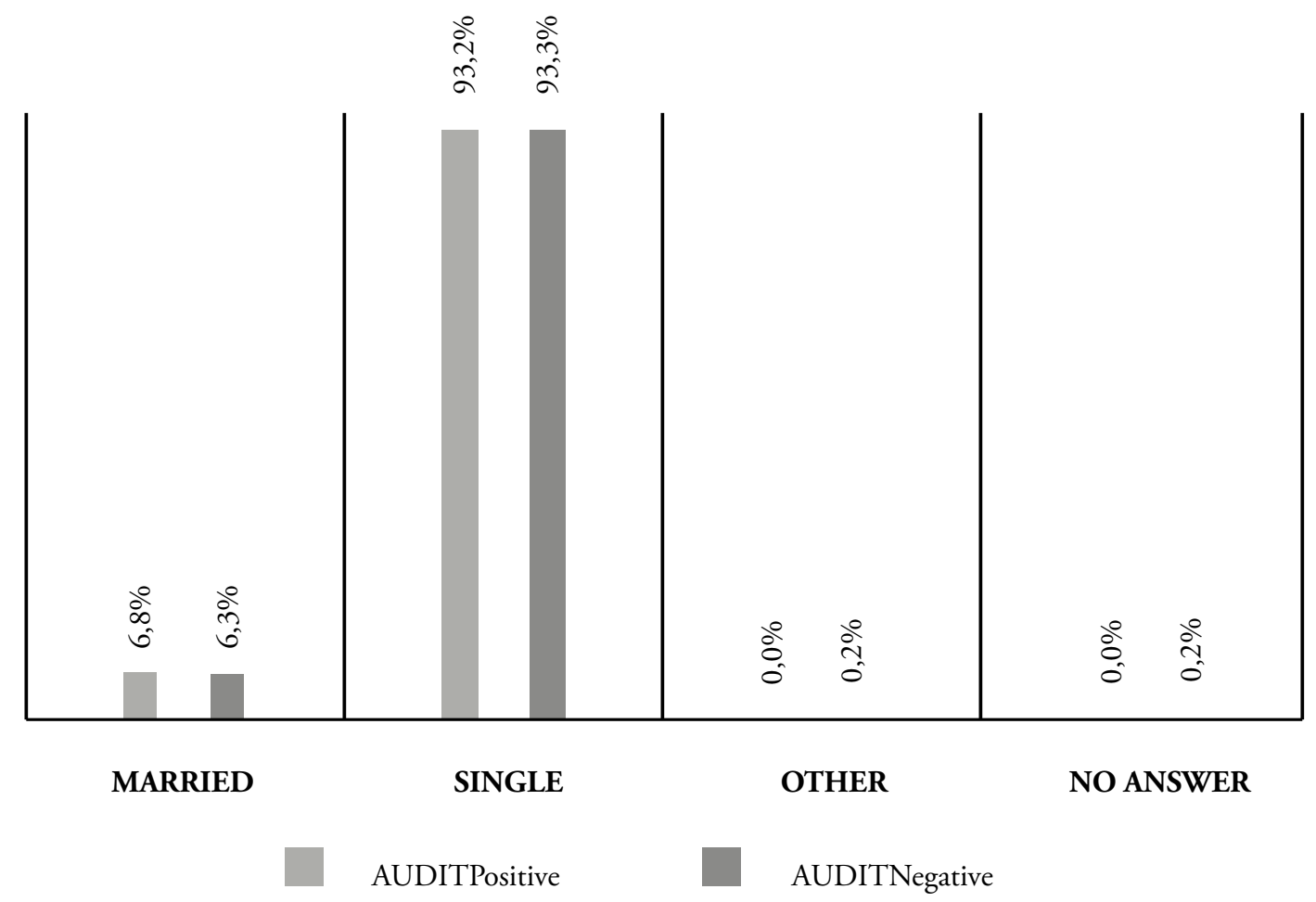

FIGURE 2 - Marital status.

Font: Elaborated by the authors.

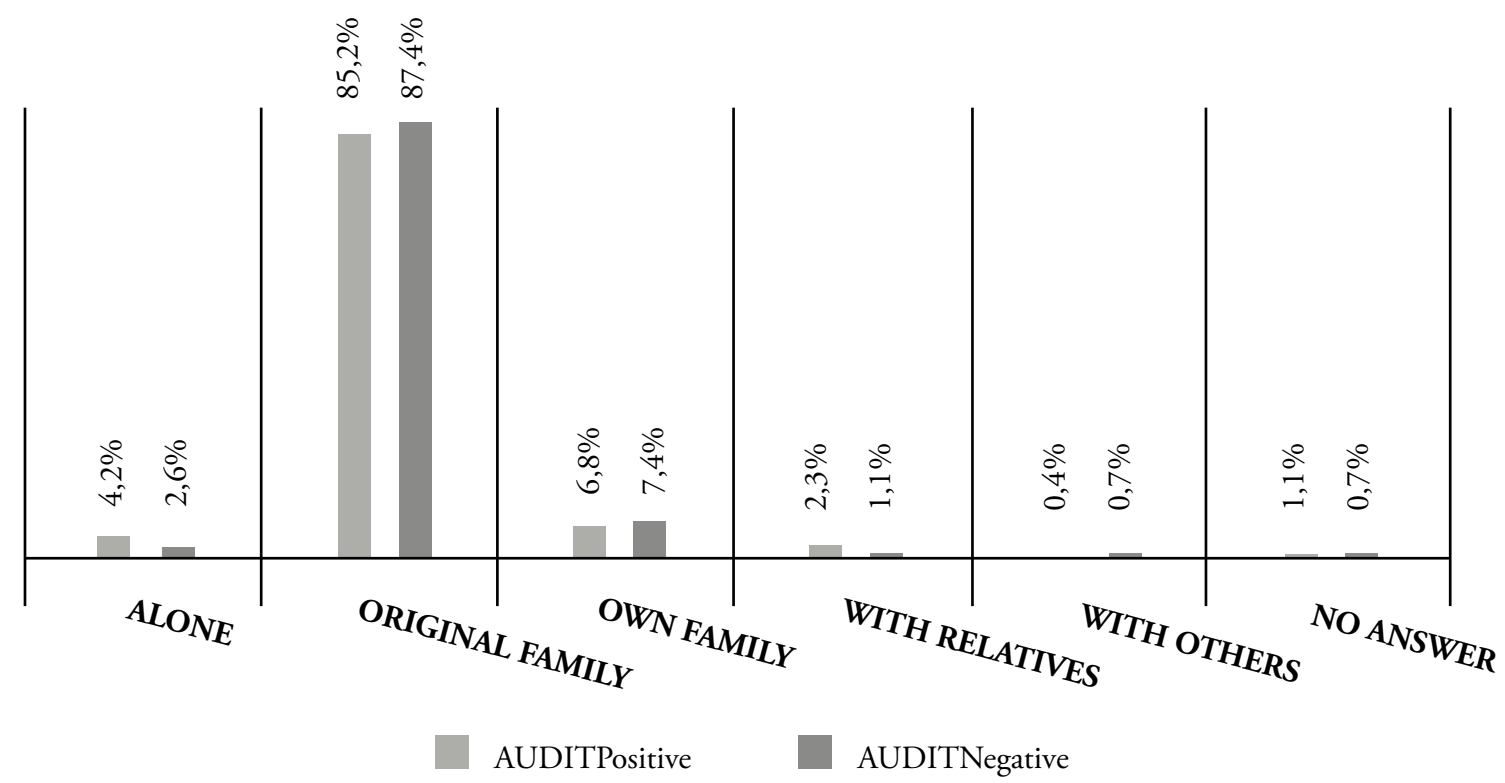

FIGURE 3 - With whom the interviewed live in his home?

Font: Elaborated by the authors. 


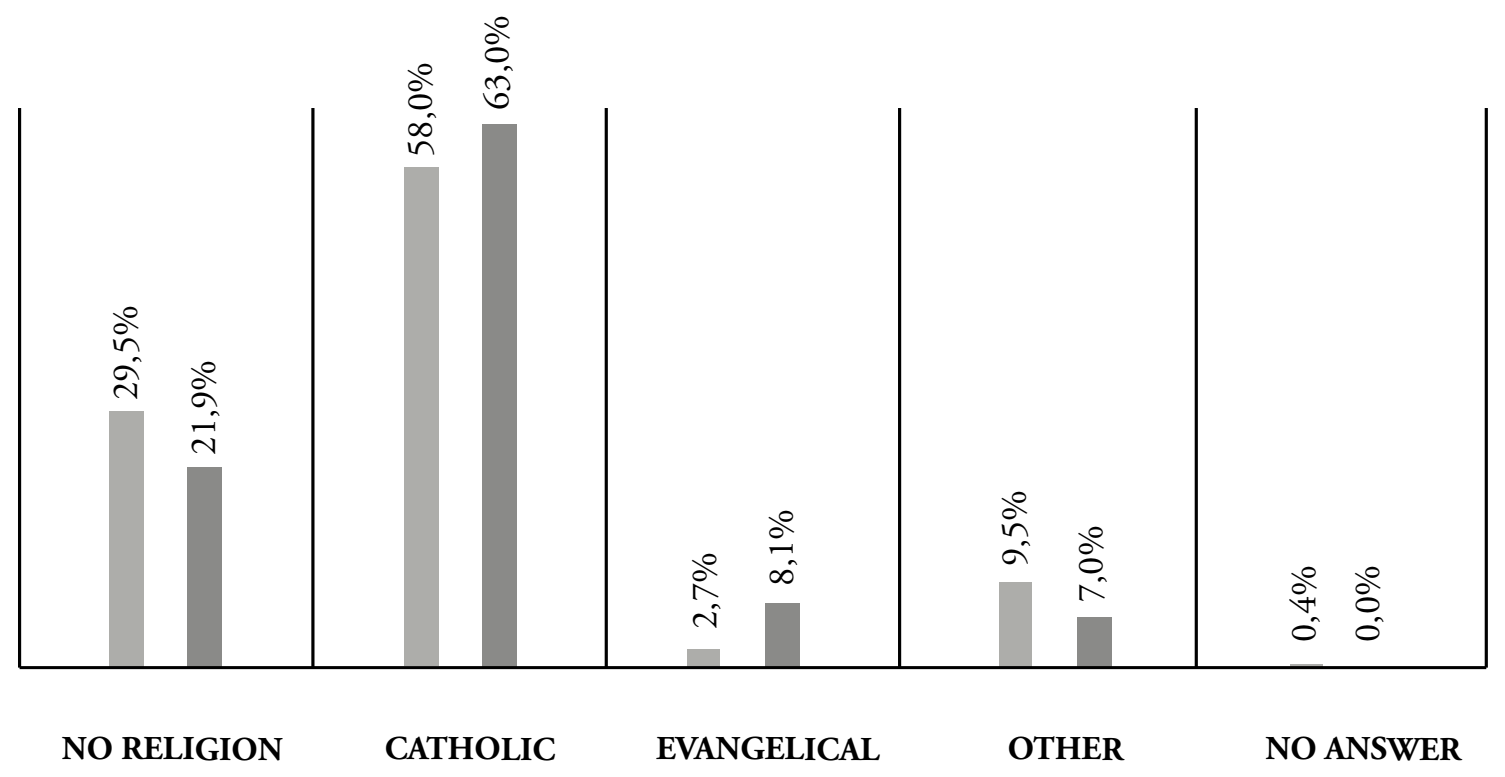

\section{AUDITPositive}

AUDITNegative

FIGURE 4 - Religion.

Font: Elaborated by the authors.

How can the relatively high level of alcohol consumption among young members of torcidas organizadas be explained? The international literature suggests that the systematic consumption of alcohol is constitutive of the lifestyle of a significant part of young members of certain football fan groups, at least within the football context. GARRIGA ZUCAL ${ }^{23}$, in his fieldwork with members of a small organized fan group (hinchada) of the Argentinean football club Colegiales, found that fighting, the use of narcotics and consumption of alcoholic beverages are recurrent practices among them. According to GARRIGA ZuCAL ${ }^{23}$, such practices aim to construct their (hyper)masculine identities and, more specifically, their identification with a certain male universe. In this universe, what makes a person to be seen as a "real man" is the fact that he resists, i.e., that he is able to withstand another person and endure the pain. This ability confers honor, prestige and symbolic capital. Within the hinchadas, the main way to perform this resistance is through fighting. The knowledge of fighting techniques and the ability to withstand the pain caused by the wounds of confrontation are highly distinctive components within these groups. In this context, the scars acquired in the 'battlefield' constitute physical evidence of masculinity, adding veracity to their reports of fights.
On the other hand, those who run away and reject the fighting, are labelled passive homosexuals or 'nonmales' - which, in this universe, is seen as a form of disgrace and humiliation ${ }^{27}$.

In isolation, the ability to handle a high level of alcohol consumption is not sufficient to confer masculinity to a hinchada member, who should always show body dexterity and resistance to pain. However, this capability enables the individual to affirm his reputation before the other members of the group, as virility demonstrated in combat. Consuming copious amounts of alcohol means, ultimately, to challenge the limits of the body ${ }^{41,42}$. In this sense, when a person appears to be intoxicated, appears to be "destroyed" by the effects of alcohol, but does not 'fall', or 'give up', this works as a sign of prestige, which reveals one's virility through the capacity to resist the effects of alcohol.

The Brazilian literature suggests that young members of torcidas organizadas are guided by a principle of masculinity that is quite similar to English hooligans and members of Argentinean hinchadas ${ }^{17,31}$ Thus, we can infer that the relatively high rate of 'risky' consumption of alcohol by those supporters, in relation to the rest of society, can be explained as a way to affirm masculine status and to show resistance, that is, to demonstrate how virile they are as 'real men'. On one hand, this consumption can be seen 
as something that, to a certain extent, enhances the stigma associated with these supporters and, of course, may increase the desire of public officials to control them ${ }^{11}$. After all, besides 'violent', they would be 'drunk'. In this sense, such consumption (or rather, the public visibility of it) may be contributing to the authorities' will to keep these young members of torcidas organizadas in a situation of domination.

On the other hand, from the fans' perspective alcohol consumption can be interpreted as a way of asserting an alternative way of life, which is opposed to the model socially established as 'normal'. According to GARRIGA ZuCAL $^{23}$, the 'abnormal', the 'pathological', is reframed by the members of hinchadas, in a way to assume a positive value. As literature suggested ${ }^{12,23}$, the high rate of 'risky' consumption of alcohol by young members of torcidas organizadas could be linked to the affirmation of a masculine identity and positively valued, then this consumption reverses directions usually attributed to this consumption, seen as something that a 'loser' or a 'sick' person would do. We suggest also that further researches investigate whether such consumption be a way of resistance to the social norms constructed and imposed by those who habitually occupy positions of dominance, as literature claims.

\section{Attendence to matches and perceptions about violence}

Regarding their game attendance, $85.9 \%$ of the interviewees reported that they attend the stadiums to watch their favorite team one to two times per week, which shows that it is a rather frequent group to football games that can be called 'loyal fans'. The frequency with which interviewees go to the stadiums can be seen in TABLE 3 .

TABLE 3 - Attendance at matches.

\begin{tabular}{lccc}
\hline & Frequency & Valid percent & Cumulative Percent \\
\hline Two times per week & 328 & 40,8 & 40,8 \\
Once times per week & 363 & 45,1 & 85,9 \\
Once per moth & 57 & 7,1 & 93 \\
Only local derby & 19 & 2,4 & 95,4 \\
Rarely & 37 & 4,6 & 100 \\
\hline Total & $\mathbf{8 0 4}$ & $\mathbf{1 0 0}$ & \\
\hline
\end{tabular}

In AUDIT positive group, $86 \%$ are loyal fans, attending football match once or twice a week on average. And, even if the game was televised, 95.6\% reported they would go to the stadium. The latter dismisses the legitimacy, at least for these fans with a relatively strong team identification, of the discourse of journalists that justifies the non-broadcasting of games in the host cities, claiming that the television would empty stadiums and fans would prefer to watch the game at home ${ }^{43}$. The vast majority of those who scored positive on the AUDIT are regular attendees at matches of their favorite teams, with $43.2 \%$ reporting that they attend every match and a further $42.8 \%$ reporting to attend almost every match. Among the respondents who scored positive on the AUDIT only a small minority of $4.5 \%$ rarely attends football matches, i.e. less than once per month.

In order not to lose this critical character of 'risky' consumption of alcohol, it is necessary to problematize the terms employed by AUDIT. The words we use are never neutral because they always express people's subjective views and situations, as well as their underlying attitudes or ideologies. For this reason, 'when we choose to name what we study with words that people involved already use, we acquire, with words, attitudes and perspectives that they imply' (p. 219) ${ }^{44}$. This begs the question: for whom is the alcohol consumption 'risky'? Clearly, it is known that the systematic consumption of alcohol can lead to addiction and bring serious consequences for the health of its users and, thus, it is danger to them ${ }^{45}$. However, the term 'risk' is ambiguous and often carries a strong moral connotation and different meanings. One of these meanings is that the person who structurally consumes alcohol does not have control over himself and, therefore, cannot avoid engaging in negative behaviours such as acts of violence. Another meaning of the term 'risk' in this context is that such consumption 
would be 'risky' to the extent that, as BECKER ${ }^{44}$ would argue, it provides pleasure without being the by-product of activities considered socially positive or productive, such as work or religious fervor. In this sense, it would be a risk to the utilitarian/conservative ideology that dictates that pleasure must, necessarily, be a result of these productive activities. Thus, in problematizing the term 'risk', we do not accept, beforehand, some unquestionable 'truths' associated with the systematic consumption of alcohol simply because they have become naturalized. Instead, our research opens the discussion to the possibility that this consumption can mobilize very different meanings that resist or subvert the 'official explanation'.

In terms of respondents' perceptions about violence related to football matches, it could be verified that their explanations coincide with existing Brazilian and European research on the topic ${ }^{46,47}$. More than $31 \%$ attribute violence on days of football games to the lack of education of the supporters, to their ignorance and stupidity, stating that some of them go to games only to fight. This portion of the fans, therefore, holds fans themselves responsible for any violence on game days. Thirty-five percent blame the rivalry between the supporters and fanaticism to the provocations of violence on game days. To $15.9 \%$, violence on game day is directly related to police violence or to lack of preparation of the police, and, among these, there are those who blame the media, the management of clubs, lack of planning and security, as well as impunity and performance of the team. As for $4.4 \%$ of interviewed, violence in football is related to supporters use of drugs and alcohol. Coincidentally, the same percentage of interviewed did not know to explain the reason for the violence on days of football games. To $5 \%$ of interviewed, the problem of violence on game day is a social problem, a reflection of society, i.e., something that does not exist only in football. Finally, $8.2 \%$ could not identify the reasons for this problem.

Regarding the perception of interviewees about the role of the media, the vast majority $(77.3 \%)$ believe that the media (newspapers, television and radio) contribute, in general, to violence in football. The data indicate that $12.8 \%$ of interviewed believe that the media manipulate information. As for $15.3 \%$ of the interviewed, this is due because the media criticize the torcidas organizadas. In turn, $3.2 \%$ could not answer and $19.4 \%$ believe that the media encourages peace.

This paper has examined the profile of young members of torcidas organizadas and their relationship with alcohol consumption. The young football fans that were surveyed for this study reported relatively high levels of alcohol consumption which, in approximately one-third of cases, can be considered 'risk' or 'high risk' according to the AUDIT criteria. However, the particular contexts within which this consumption occurs was not established in the study. This is a significant limitation of our study. Future research is needed to determine whether there are any significant differences in patterns of alcohol consumption among young male fans in different life domains (e.g. at home, school, nightlife). This could be done, for instance, by complementing the present study with qualitative approaches that provide a deep insertion into the social worlds of young male football fans in Brazil.

The present study further indicates a need to qualify and contextualize any direct relationship between alcohol and violence in football. Although often labeled violent by the media, young male fans who drink heavily do not necessarily engage in, or condone, violent behaviour. On the contrary, as suggested by Lopes ${ }^{14}$, this label is both unfounded and discriminatory. Our study does, however, confirm the hypothesis that alcohol and violence are related in that both activities seem to be guided by a principle of masculinity that features centrally in the cultural practices of young football fans in Brazil. This figuration, in which drinking 'dangerously' becomes a way of masculine affirmation, is arguably further enhanced by beer advertising, including brands related to football games or national teams.

\section{Notes}

a. This research received funding from the Brazilian Ministry of Sports, in an announcement of the Group CEDES (Center for the Development for Recreational Sports and Leisure Activities). 


\section{Resumo}

\section{Bebendo perigosamente? Jovens torcedores de futebol, álcool e masculinidade no Brasil}

Este artigo analisou os jovens membros das torcidas organizadas de futebol e sua relação com o álcool. Essa relação foi investigada com base em um survey por meio do qual foram entrevistados 804 torcedores do estado de São Paulo, Brasil. Os resultados do survey indicaram que o percentual de jovens que se envolve com o uso abusivo de álcool é consideravelmente mais alto que a média da faixa etária no Brasil. Comparando com jovens de outros países, argumentamos que essa taxa alta é relacionada às práticas culturais que envolvem os jovens torcedores, nas quais beber "perigosamente" é um elemento constituinte da masculinidade no contexto do futebol.

Palavras-Chave: Futebol; Álcool; Torcidas organizadas; Masculinidade; Fanatismo.

\section{References}

1. Nicholson M, Hoye R, Brown K. Alcohol and community football in Australia. Int Rev Sociol Sport. 2014;49(3/4):293-310.

2. Adams J, Coleman J, White M. Alcohol marketing in televised international football: frequency analysis. BMC Public Health. 2014;14:473.

3. Dunning, E. Towards a sociological understanding of football hooliganism as a world phenomenon. Eur J Crim Pol Res. 2000;8(2):141-62.

4. Peitersen B. Roligan: un modo d'essere dei tifosi danesi. In: Roversi A, editor. Calcio e violenza in Europa. Bologna: Il Mulino; 1990. p. 169-86.

5. Giulianotti R. Football and the politics of carnival: an ethnographic study of Scottish fans in Sweden. Int Rev Sociol Sport. 1995;30(2):191-220.

6. Frosdick S, Marsh P. Football hooliganism. Cullompton: Willan; 2005.

7. Lemle R, Mishkind ME. Alcohol and masculinity. J Subst Abuse Treat. 1989;6:213-22.

8. Palmer C. Key themes and research agendas in the sport-alcohol nexus. J Sport Soc Issues. 2011;35(2):168-85.

9. Giulianotti R. Scotland's tartan army in Italy: The case for the carnivalesque. Sociol Rev. 1991;39(3):503-27.

10. Robson G. No one likes us, we don't care: the myth and reality of Millwall fandom. Oxford: Berg; 2000.

11. Pearson G. An ethnography of English football fans: cans, cops and carnivals. Manchester: Manchester University Press; 2012.

12. Alabarces P. "Aguante" and repression: Football, politics and violence in Argentina. In: Dunning E, Murphy P, Waddington I, Astrinakis AE, editors. Fighting fans: football hooliganism as a world phenomenon. Dublin: University College Dublin Press; 2002. p. 23-36.

13. Pearson G, Sale A. On the lash: revisiting the effectiveness of alcohol controls at football matches. Policing Soc. 2011;21(1):1-17.

14. Lopes FTP. Discursos sobre violência envolvendo torcedores de futebol: ideologia e crítica na construção de um problema social [tese]. São Paulo: Universidade de São Paulo; 2012.

15. Murad M. Violência e o futebol: dos estudos clássicos aos dias de hoje. Rio de Janeiro: Editora FGV; 2007.

16. Thompson K, Palmer C, Raven M. Drinkers, non-drinkers and deferrers: reconsidering the beer/footy couplet amongst Australian Rules football fans. Aust J Anthropol. 2011;22(3):388-408.

17. Pimenta CAM. Torcidas organizadas de futebol: violência e auto-afirmação - aspectos da construção das novas relaçóes sociais. São Paulo: Vogal; 1997.

18. Russell GW. Sport riots: a social-psychological review. Aggress Violent Behav. 2004;9:353-78.

19. Monteiro RA. Torcer, lutar, ao inimigo massacrar: Raça Rubro-Negra! Uma etnografia sobre futebol, masculinidade e violência. Rio de Janeiro: Editora FGV; 2003.

20. Spaaij R. Men like us, boys like them: violence, masculinity, and collective identity in football hooliganism. J Sport Soc Issues. 2008;32(4):369-92.

21. Armstrong G. Football hooligans: knowing the score. Oxford: Berg; 1998.

22. Hughson J The boys are back in town: soccer support and the social reproduction of masculinity. J Sport Soc Issues. 2000;24(1):8-23. 
23. Garriga Zucal J. "Soy macho porque me la aguanto": etnografía de las prácticas violentas y la conformación de identidades de género masculinas. In: Alabarces P, Conde M, Dorado C, editores. Hinchadas. Buenos Aires: Prometeo; 2005. p. $39-58$.

24. Spaaij R, Geilenkirchen M. Ta(l)king sides: ethical and methodological challenges in comparative fieldwork on avid football rivalries. Soccer Soc. 2011;12(5):633-51.

25. Reis HHB. Lei Geral da Copa e o processo de criação da legislação sobre violência. Movimento. 2012;18(1):69-99.

26. Rodrigues VMB. Bebidas alcoólicas e estádios de futebol. Jus Navigandi [Internet]. 2012 [citado 2019 mar. 1];17(3352). Disponível em: https://jus.com.br/artigos/22554/o-esporte-bretao-a-copa-do-mundo-e-as-bebidas-alcoolicas.

27. España. Dictamen de la Comisión Especial de Investigación de la Violencia en los Espectáculos Deportivos, con especial referencia al fútbol. Madrid: Senate; 1990.

28. Buford B. Entre os vândalos: multidão e a sedução da violência. São Paulo: Companhia das Letras; 1992.

29. Garriga Zucal J. Pibitos chorros, fumancheros y con aguante. El delito, las drogas y la violencia como mecanismos constructores de identidad en una hinchada. In: Alabarces P, Conde M, Dorado C, editores. Hinchadas. Buenos Aires: Prometeo; 2005.

30. Costa Neto PL. Estatística. São Paulo: Edgard Blucher; 1977.

31. Gil AL. Como elaborar projetos de pesquisa. 5a ed. São Paulo: Atlas; 2010.

32. Romera L, Reis HHB. Uso de álcool, futebol e torcedores jovens. Motriz. 2009;15(3):541-51.

33. Saunders J, Aaslang O, Babor T, De La Fuente J, Grant M. Development of the Alcohol Use Disorders Identification Test (AUDIT): WHO collaborative project on early detection of persons with harmful alcohol consumption, II. Addiction. 1993;88:791-804.

34. Mendez EB. Uma versão brasileira do AUDIT (Alcohol User Disorders Identification Test) [tese]. Pelotas (RS): Universidade Federal de Pelotas; 1999.

35. Lima CT, Freire ACC, Silva APB, Teixeira RM, Farrell M, Prince M. Concurrent and construct validity of the AUDIT in an urban Brazilian sample. Alcohol Alcohol. 2005;40(6):584-89.

36. Martins RA, Manzatto JA, Cruz LN, Poiate SMG. Scarin ACCF. Utilização do AUDIT para identificação do consumo de álcool entre estudantes do ensino médio. Interam J Psychol. 2008;42(2):307-16.

37. Martins RA. Uso de álcool, intervenção breve e julgamento sócio-moral em adolescentes que bebem excessivamente [tese]. Marília: Universidade Estadual Paulista Júlio de Mesquita Filho; 2006.

38. Mendoza-Sassi RA, Béria JU. Prevalence of alcohol use disorders and associated factors: a population-based study using AUDIT in southern Brazil. Addiction. 2003;98(6):799-804.

39. Barros MBA, Botega NJ, Dalgalarrondo P, Marín-León L, Oliveira HB. Prevalence of alcohol abuse and associated factors in a population-based study. Rev Saúde Pública. 2007;41(4):502-9.

40. Laranjeira R, Pinsky I, Zalesky M, Caetano R. I Levantamento Nacional Sobre padróes de Consumo de Álcool na População Brasileira. Brasília: Senad; 2007.

41. Alabarces P. Crónicas del aguante: fútbol, violencia y política. Buenos Aires: Capital Intelectual; 2004.

42. Alabarces P. "Aguante" and repression: football, politics and violence in Argentina. In: Dunning E, Murphy P, Waddington I, Astrinakis AE, editors. Fighting fans: football hooliganism as a world phenomenon. Dublin: University College Dublin Press; 2002, p. 23-36.

43. Escher TA, Reis HHB. Os supostos espaços de discussão futebolística na televisão: as mesas redondas. Rev Bras Ciênc Esporte. 2012;34(1):197-215.

44. Becker HS. Outsiders: estudos de sociologia do desvio. Rio de Janeiro: Zahar; 2009.

45. World Health Organization (WHO). Global Status Report on Alcohol and Health. Geneva; 2011.

46. Reis HHB. Futebol e violência. Campinas: Autores Associados; 2006.

47. Reis HHB. A violência nos estádios: estudo comparado entre Brasil e Espanha [tese]. Campinas: Universidade Estadual de Campinas, 2004.Equid quaes ant. Hillest, natas aut evellit estrum, explabo rendusdae eatint.

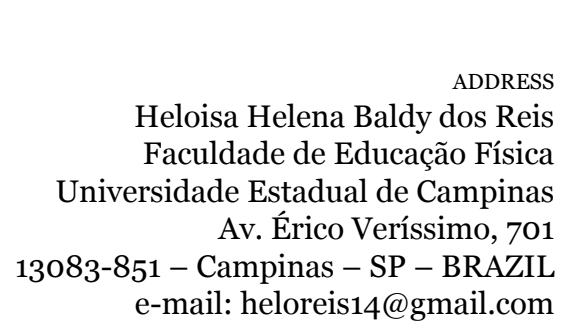

Submitted: 30/07/2015

Revised: 07/02/2018

Accepted: 29/03/2018 